\title{
Ageing policy in Poland during the COVID-19 pandemic
}

\author{
Piotr Lutomski ${ }^{1, A-D \oplus}$, Monika Kaczoruk ${ }^{1, A-D \oplus}$, Magdalena Florek-ŁuszCzki ${ }^{1, E-F \oplus}$ \\ ${ }^{1}$ Institute of Rural Health, Lublin, Poland \\ A - Research concept and design, B - Collection and/or assembly of data, C - Data analysis and interpretation, \\ $D$ - Writing the article, E-Critical revision of the article, F-Final approval of the article
}

\begin{abstract}
Lutomski P, Kaczoruk M, Florek-Łuszczki M. Ageing policy in Poland during the COVID-19 pandemic. Ann Agric Environ Med. $2021 ; 28(4): 551-557$.
\end{abstract} doi: $10.26444 /$ aaem/143559

\begin{abstract} and the quality of life of seniors before and during the COVID-19 pandemic. of the quality of life by the WHO. $62 \%$ of seniors, and difficulties with access to health care system services. of Polish society.

\section{Key words}

COVID-19 pandemic, public health, older adults, ageing policy programmes
\end{abstract}

Introduction and objective. Poland is engaged in the implementation of activation programmes for seniors at governmental as well as non-governmental levels. Among these programmes may be mentioned, 'Active+', 'Senior+', 'Care 75+', and 'Senior Caritas'. The COVID-19 pandemic highlighted the need for the inclusion of seniors into social life, and concern about their health. An important challenge for social and ageing policy is the provision of proper standards of care and health protection, especially during an increased sanitary regime. The aim of the study was analysis of the ageing policy strategy

Review methods. The study was conducted by the method of analysis of data in the area of national initiatives concerning activation programmes for seniors implemented during 2020-2021. The starting point was the well-established definition

Abbreviated description of the state of knowledge. The analysis performed showed a multitude of factors determining the needs of seniors at the time of the pandemic, which often differed from those observed earlier. The latest studies of the quality of life of the elderly in Poland demonstrated that nearly $60 \%$ of respondents assessed their psychological condition as worse than before the pandemic. Another problem was the issue of physical activity, which was limited by more than

Summary. It seems necessary to implement forms of assistance which could be adjusted to the changing epidemiological conditions, in order to improve the quality of life of persons who, in the near future, will constitute a considerable percentage

\section{INTRODUCTION AND OBJECTIVE}

The past century has provided people with an increase in life span by more than 30 years. Researchers agree on the fact that a profound social revolution is underway - the Age Revolution $[1,2]$. The synergistic effect of reducing infant mortality, combined with a low or even negative natality rate and an increase in life expectancy, has resulted in an important reconstruction of the demographic structure of many countries.

The ageing process is characterized primarily by a decreased physical and psychological fitness performance. During this time, a clear increase in morbidity is observed, there occur problems with general motor skills, mobility and communication, which frequently lead to regression of social roles and, consequently, exclusion and marginalization of the individual. There is then an increased risk of the occurrence of the phenomenon of age discrimination, so-called ageism [3]. Attention should be paid to the fact that the needs of the elderly clearly correlate with the quality of life perceived by them. According to the definition by the World Health Organization (WHO) of 2002, active ageing is: 'the process of optimizing opportunities for health, participation, and security in order to enhance quality of life as people age' [4]. This definition widely deals with activity biased mainly on

Address for correspondence: Monika Kaczoruk, Institute of Rural Health, Lublin Poland

E-mail: kaczoruk.monika@imw.lublin.pl

Received: 15.10.2021; accepted: 02.11.2021; first published: 16.11.2021 the goal which is an improvement in the quality of life of the seniors themselves. In this view of active ageing it was emphasized that activity should not be associated exclusively with occupational activity or physical condition, because it refers to any domain of life: social, economic, cultural, spiritual, or civic $[5,6]$.

According to J. Czapiński and P. Błędowski, the factors which to the greatest extent decide about the quality of life of seniors are primarily: state of health, family situation, satisfaction of material needs (including accommodation), and provision of social and family support [7]. These factors become of the utmost importance at senior age. This results from hindered access to cultural and care facilities, as well as the lack of information concerning available health programmes, organized cultural and educational events, or transport and economic difficulties, which make it impossible to participate in this type of initiatives outside the place of residence. These problems may concern especially those who are lonely, non-mobile, or are unable to take advantage of ad hoc assistance from their family or acquaintances [8]. The COVID-19 pandemic highlighted the need for inclusion of seniors into social life, and concern about their health. From 14 March 2020, Polish citizens were told not to leave their houses unless absolutely necessary. Later, from 12 25 March 2020, the government closed all institutions for seniors activities [9].

Quite often, seniors have difficulties with using the developing information technologies. This concerns, among other things, use of the Internet which offers a wide range 
of information about events organized in the immediate vicinity, or convenient forms of contact with the closest persons by means of instant messengers [10]. While using the research tools assessing the needs of the seniors, it is possible to delineate the direction of intervention related with an effective educational and activation management. An individual approach to elderly persons seems to be the key to the recognition of their actual needs which significantly determine the quality of life, and may also result in the limitation of the phenomenon of escalation of the phenomenon of gerontophobia occurring in society [11]. It is justifiable to analyze the strategy of ageing policy, with consideration of the period of pandemic, in order to assess the accessibility of the seniors to socio-cultural and health promoting initiatives.

\section{REVIEW METHODS}

Analysis of ageing policy programmes and quality of life of seniors. The study was conducted by the method of data analysis - desk research. This study of the social activation of seniors in Poland focuses on analysis of national initiatives concerning the programmes of social activation of seniors before and during the COVID-19 pandemic.

In addition, the quality of life of the elderly during the pandemic was examined. Articles from journals qualified for review included those which provided information concerning interventions biased on recognition of the quality of life of Polish senior citizens at the time of the pandemic. The starting point was the already well-established definition of the quality of life by the WHO, according to which the Quality of Life (QoL) is: 'individuals' perception of their position in life in the context of the culture and value systems in which they live and in relation to their goals, expectations, standards and concerns' [12]. The indicators of the QoL for the elderly are usually individual factors, such as health, physical activity, socio-economic stability and personal control, as well as network factors, such as social life, family relations, care network and support system [13]. As a consequence of such an understanding of the concept of the quality of life, the literature review focused on consideration of key words included in the above-mentioned definition, taking into account seniors living in Poland and period of the coronavirus pandemic in 2020-2021. Articles in Polish and English were sought using the terms: 'elderly', 'senior', 'wellbeing', 'satisfaction with life', 'quality of life', 'Poland', 'COVID-19', 'coronavirus', 'pandemic', 'ageing', 'elderly', 'loneliness', and 'social isolation' (key words searched individually and combined with operator 'and'). Studies contained in this literature review were sought in four databases: Web of Science, Google Scholar, PubMed, and Scopus. The inclusion criteria were: articles about the quality of life, articles assessing the impact of the pandemic on the lives of seniors in Poland, and scientific articles published in 2020-2021. The exclusion criteria were: research carried out in countries other than Poland, age groups under 60, unsystematic reviews, letters, comments and editorials, case reports or case series with less than 30 people.

\section{STATE OF KNOWLEDGE}

Ageing policy programmes. Ageing policy is a part of social policy which places the elderly in the focus of interest. It may be assumed that ageing policy is: 'all intentional actions of public administration bodies at all levels, and other organizations and institutions which pursue initiatives shaping conditions for dignified and healthy ageing'. The task of ageing policy is primarily creating such opportunities for the elderly which would support them in an active, independent ageing, with consideration of understood health, care, or rehabilitation needs, as well as social activation or occupational, educational, or cultural activity [14].

The Active Ageing Index (AAI) serves to define directions for constructing policy for an active and healthy ageing. This index has been developed within a joint project carried out by the European Commission's Directorate General for Employment, Social Affairs and Inclusion, and the European Commission and the United Nations Economic Commission for Europe, in close association with a number of political initiatives functioning at the European level. AAI is an index consisting of 22 individual indicators, and is obtained by combining score results from four domains, i.e. employment, participation in social life, independent, healthy and safe life, opportunities, and conditions favouring an active ageing [15]. Based on the four factors included in the index of the quality of life AAI, it is possible to assess Polish ageing policy. The so-called Madrid International Plan of Action on Ageing is also noteworthy, coordinated by the Unites Nations, in which the most important areas of social actions with respect to the elderly were formulated. While synthetizing the provisions contained in the document, the team of $\mathrm{P}$. Błędowski characterized a network of actions on behalf of seniors which included the following areas: construction of a society friendly for people at any age, education of the elderly in order to compensate for disproportions in the development of individual regions, strengthening intergenerational ties, concern about good state of health and wellbeing of the elderly, and provision of care for persons who are not independent [16].

The basic legal Act which regulates the necessity for conducting evaluation of Polish ageing policy is the Act in the matter of the elderly of 11 September 2015, which imposes the duty to monitor and issue an annual report concerning the situation of the elderly by public administration bodies, State organizational entities, and other organizations engaged in shaping the situation of the elderly. As indicated in Article 3 of the above-mentioned Act, the monitoring of the situation of the elderly covers: 'demographic situation, income situation, housing conditions, occupational activity, family situation and structure of households, situation of the disabled, social and citizenship activity, educational and cultural activity, sports and recreational activity, state of health, availability and level of social services, equal treatment and counteracting age discrimination' [17].

The key directions of the national ageing policy have been included in the document Social policy with respect to the elderly until 2030. Safety. Participation. Solidarity [18]. Its goal is to provide complex services assisting the elderly with functioning in the social environment. Social policy with respect to the elderly until 2030, is the first government document delineating specified areas of actions and indicates entities directly responsible for their implementation. It 
considers solutions in all the most important spheres of life of the elderly, among others, in the field of safety and health, counteracting loneliness, active participation in social life, as well as adjustment of infrastructure to the needs and capabilities of such persons. The document includes implementation of many actions with respect to seniors within several fields, the most important of which are: shaping the positive perception of ageing in society, participation in social life, health promotion, prevention of diseases, access to diagnostics, treatment and rehabilitation, and education for old age. In addition, the Programme contains proposals for actions addressed directly to dependent seniors.

Detailed elaborations in the area of ageing policy on the national level have been developed by the Minister of Family and Social Policy. The currently implemented national strategy for ageing policy aimed at the social activation of seniors focuses on the following three programmes.

Multi-annual programme on behalf of the Elderly 'Active+' for 2021-2025. This programme was sanctioned by Resolution No. 167 by the Council of Ministers of 16 November 2020 on the establishment of a multi-annual programme on behalf of the Elderly 'Active+' for 2021-2025. The Programme considers the directions of actions resulting from the above-mentioned document adopted by the Council of Ministers entitled: Social policy with respect to the elderly until 2030. Safety. Participation. Solidarity. The main goal of the Programme 'Active+' is provision for the elderly of dignified, safe and active old age by increasing participation of the elderly persons in all domains of social life [19].

The initiative preceding the Programme 'Active+' was the Government Programme on behalf of Social Activity (Social Activity of the Elderly - ASOS). The main goal of this Programme was supporting non-government organizations by providing funding for the projects for the elderly implemented by these organizations in four priority areas: education of the elderly, social activity promoting intra- and inter-generational integration, social participation and social services for the elderly [20]. During the Sejm session of 17 March 2021, the Deputy Minister of Family, Labour, and Social Policy, S. Szwed, evaluated that the Programme still enjoys great interest, and assured that the programme would be continued in 2021-2025 [21, 22].

Multi-annual programme 'Seniort' for 2021-2025. The programme was established by Resolution No. 191 of the Council of Ministers of 21 December 2020 on the establishment of a multi-annual programme 'Senior+' for 2021-2025, which is the continuation of the multi-annual programme for 2015-2020. The goal of the Programme is to increase the active participation of seniors in social life by providing financial support for local government units. The funds allocated for this purpose serve for the creation or expansion of infrastructure of the support centres in the local environment, and increasing the number of places in 'Seniort' support centres.

Programme 'Care 75+'. The strategic goal of the programme 'Care 75+' for 2021 is improvement in the availability of care services, including specialist care services for persons aged 75 and over who live in communes with a population of up to 60,000 inhabitants. This programme is an element of State social policy in the field of provision for the above- mentioned persons of support and assistance adequate to the needs and capabilities resulting from their age and state of health, within care services, including specialist care services, improvement in the quality of life of seniors, and financial support for communes in the area of provision of care services [23].

Ageing policy is an important element of the functioning of social policy. At the time of the COVID-19 pandemic, an important challenge for social policy, including ageing policy, is the provision of appropriate standards of care and health protection for seniors. During the 15th meeting of the Ageing Policy Committee on 13 April 2021, it was indicated that at the time of the pandemic, the ageing policy programmes had been implemented in $94 \%$ of the programmes assumed. In association with prevention, counteraction and control of coronavirus infections, the decision was made to suspend activities under government programmes for social activation of seniors, i.e. Daycare Homes Senior+, and Clubs Senior+. Despite closing care facilities for seniors it was possible to implement programmes included in the projects ASOS and 'Senior+' [24].

The project Support Senior is closely adjusted to the pandemic conditions [25]. This Programme assumes financial support for communes in the area of organization and implementation of the support service, consisting especially in the delivery of shopping containing essentials, including food products, and personal hygiene products for seniors in need. The Programme had been planned for implementation until 31 December 2021. Within the Programme, the Ministry of Family and Social Policy also created the Solidarity Assistance Corps for the Seniors [25]. A helpline dedicated to seniors was also launched; by calling the indicated phone number older persons may ask for help with activities requiring leaving the house which are hindered by the presence of pandemic. The National Institute of Freedom - Centre for Civil Society Development, supported by sixteen partners from each province, is responsible for the implementation and financing of the Solidarity Assistance Corps for the Seniors. It is noteworthy that within the project steps have been undertaken enabling work during the pandemic, by adjusting adequate safety measures for both volunteers and target recipients.

Home quarantine created the need for including seniors in social life and rendered the need for concern about their health even more visible. Within the national ageing policy at the time of pandemic, the Ministry of Family and Social Policy also supported the prophylactic programme of the Ministry of Health: 'Active senior at home'. The Polish Chamber of Physiotherapists, together with the Ministry of Health, developed a set of safe exercises which, on assumption, would facilitate the undertaking of activity by seniors. The exercises are available on the special website: fizjoterapiaporusza.pl, and YouTube channel of the Ministry of Health. Every day on this website there appears one film with an exercise, together with a commentary by an expert, and guidelines concerning the number of repetitions or pace [26].

Intergenerational projects. The concept of intergenerational projects, often based on the principles of volunteering, has become an important branch of ageing policy, especially at the time of pandemic. This idea consists in supporting individuals from various generational groups by the provision of mutual assistance. Seniors who have problems 
with frequent going out may obtain help form a younger age group, which offers, e.g. carrying out basic grocery shopping, while young parents who need temporary care for their children, may use their free time and experience of their older neighbours. Such solutions enable making contact and becoming acquainted with unrelated people at various ages, which may result in a reduction in the scale of age segregation, minimization of the phenomenon of loneliness, or debunking numerous stereotypes concerning individual age groups. The intergenerational project, on assumption, should be of an inclusive character which would develop the capabilities of its participants, thus creating conditions to use multiple resources available to representatives of various age generations. Such a solution would be of immediate benefit for all participants in the project, which is one of the main goals of the concept of intergenerational projects $[27,28]$.

Actions in the field of intergenerational cooperation cover several domains of life, including education focused on mutual learning, acquisition of experiences and skills. On the one hand, this may be unique content passed down traditionally from generation to generation, whereas on the other hand, may be technical skills much needed nowadays, related, e.g., with the operation of a computer or smartphone. In such actions may be engaged, e.g., business entities which are biased on the transfer of knowledge, experiences, and skills between experienced and new employees. An important area of actions are also tourism and recreation. Their scope includes, among other things, organization of hiking and walking tours, allowing the learning of history directly from 'living witnesses', i.e. seniors who have been living in a given area for decades and remember important historical events and changing architecture. The subsequent element of intergenerational projects is the sphere of culture, including customs, becoming acquainted with diverse value systems, regional traditions or local cuisine, the recipes of which are often passed down from generation to generation. An example of such actions may be the joint implementation of various projects in the form of 'performance', or making handicrafts characteristic of a given region.

In the case of large cities, the issue of proper organization of living quarters is very important and in such a way that they do not create intergenerational barriers. A frequent phenomenon is the accumulation of seniors in older residential areas, while the young generation prefers new buildings. It is therefore crucial to create spheres consisting of mixed generations which would enable mutual assistance and support adequate to the needs of its users.

A considerable number of currently implemented intergenerational projects connects the above-mentioned spheres of life. An example of such actions is participation together on a trip, which is finalized by electronic documentation in the form of photographs or films. While the seniors are the guides of the trip, the younger participants offer assistance with downloading, processing or publishing electronic material. Such a project combines tourist, cultural and educational elements [22, 23, 29].

Intergenerational volunteering is most often based on supporting individuals from other age groups who need constant care. These may be actions provided by institutions or private households. An example of correct practices within the range of intergenerational projects, among others, is Senior Caritas, the goal of which is improvement of the quality of life of seniors and volunteers by activation, support, and creation of intergenerational bonds in local communities. During the pandemic, young volunteers offered their assistance with regular supply of meals for the most needy seniors, provided remote tutoring concerning modern technological solutions, created a daily magazine in the form of a blog, as well as organizing weekly meetings on-line. One of the important long-term assumptions associated with the project is maintaining personal relationships between its participants, especially during the period of social isolation caused by the COVID-19 pandemic [30].

The subsequent intergenerational project in line with the assumptions of ageing policy is the project Socially active. The creators of this concept is the Gdańsk Foundation 'You too can do everything', and an Independent Secondary School in Gdańsk. The goal of the project is the creation and maintenance of intergenerational bonds, based on appropriate mechanisms of intergenerational relations, mutual respect, and creation of a positive image of seniors in society. The achievement of this goal is possible due to systematic workshop actions in small groups, or direct cooperation between participants of various ages. The project is practically cost-free. Adolescents attending secondary school play the role of volunteers, while the duties demanding the greatest engagement are organizational and conceptual issues concerning the topics of meeting which would be of interest to both parties [22].

Internet and telephone consultation point: Students for Seniors is a project launched at the beginning of 2020 as the answer to the seniors' demand for drug and activity consultations, resulting from a limited access to health care facilities or activation centres. Students offer their help by phone or instant messengers, conduct a health interview, give advice (previously consulted with a teacher), or arrange the date of the next consultation. If necessary, they also carry out monitoring of the recommended solutions. The variety of reports allow the students to acquire comprehensive knowledge of health problems, due to which the project is in line with the assumptions of the intergenerational concept, and the consultations play the role of practical classes which were suspended at universities in 2020 [31]. The study conducted by the IPSOS among beneficiaries of the project: 'For everyday shopping' shows that $84 \%$ of seniors evaluate their contact with a volunteer as necessary or very necessary. In turn, $82 \%$ of volunteers achieved high or very high satisfaction with their work. In 2021, the project which consists in year-round assistance for the elderly and lonely, annually covers more than 10,000 seniors and 3,300 volunteers, thus by nearly a half as many as in 2018. This results from the fact of an increasing number of people at old age in society, their difficult financial situation, and the demand for contact and activation [32].

Analysis of the quality of life of seniors during the pandemic in Poland. According to the results of studies concerning the quality of life of the elderly during the first year of the COVID-19 pandemic, carried out in 2021 by Polish research unit SeniorHub, more than a half of respondents ( 60\%) described their psychological condition as worse, compared to that before the pandemic. Psychological status significantly determined the quality of life of seniors. A study by M. Gambin et al. (using questionnaires: the Patient Health Questionnaire-9, the Generalized Anxiety Disorder-7, a Scale of Perceived Health and Life Risk of COVID-19, 
a Social Support Scale, and a Scale of Pandemic-Related Difficulties) also demonstrated that anxiety and uncertainty associated with the spread of the COVID-19 pandemic were a significant predictor of fear and depressive symptoms among persons aged 45-59 and 60-85 [33]. However, researchers engaged in a study conducted among Polish and German populations entitled: 'Psychological coping, possibilities of crisis intervention and post-operative care in facilities and institutions for adults, parents, and children' arrived at different conclusions in the context of the effect of pandemic on the psychological status of seniors. The researchers used validated self-report questionnaires and indicated that persons from the oldest age groups coped with the period of pandemic better than those from younger age groups. The results demonstrated that the higher the assessment of the quality of life, wellbeing, and satisfaction with life among the elderly who participated in the study, may be associated with both their education (the majority reported higher education $-61.7 \%$, i.e. more than in the total sample), and financial stability (the majority being entitled to oldage pension). Opposite to younger persons, the pensioners were not threatened with the loss of employment. A higher assessment of the quality of life, wellbeing, and satisfaction with life in the examined sample of the elderly was also related with a lower level of psychological fear. Despite the satisfactory results, the researchers also indicated that it is necessary to implement various forms of assistance in improving psychological resources favouring the quality of life of the elderly, including the reduction of stress, as well as methods based on cognitive behavioural therapy. This is because creative and social actions which maintain affiliation to a social group, support a positive ageing process [34].

Another aspect which determined the quality of life of seniors was the issue of physical activity and using public space at the time of the pandemic. According to the results of research conducted using the Computer-Assisted Web Interview (CAWI) method, more than $62 \%$ of seniors limited their physical activity, which unequivocally correlated with the general wellbeing of the elderly. It is noteworthy that the lack of physical activity in combination with hindered access to the health sector may have significantly contributed to the increase in mortality in this age group. A study conducted between April-May 2020 concerning the needs and concerns accompanying the elderly in the light of changes in social life caused by the presence of coronavirus COVID-19, confirmed an intensification of the feeling of fear while using public space $(55 \%$ of seniors declared such concerns) [35]. The feeling of fear while using public space was significantly related with the limitation of social contacts. A high percentage of seniors in the study $(60 \%)$ declared that the most important problem during the pandemic was lack of direct contact with close persons and other people, and longing for nature during the period of social isolation. The oldest seniors (aged over 80) declared that limitations concerning the possibility of going shopping independently created a psychological load resulting from the isolation. Among other problems, the seniors also indicated longing for an additional occupational activity, contact with physicians, and the possibility to travel [35]. The above-mentioned data were also confirmed by a previously mentioned study in which nearly a half of respondents (46\%) reported that during the time of the pandemic they reduced their social contacts, which consequently decreased their quality of life. $34.6 \%$ of respondents declared that they experienced considerably greater irritation and psychological anxiety, compared to the period before the pandemic.

As a result of the COVID-19 pandemic, health care systems worldwide had to reorganize the majority of their services in order to adjust to many unprecedented circumstances. Despite the fact that some European countries expanded the right to medical services financed from public resources, there occurred new barriers in access to health care. A study aimed at establishing whether during the first months of the pandemic it came to discrimination connected with outcome in the area of unsatisfied health care needs among the elderly in Europe, showed the alarming phenomenon of the limitation of seniors' access to health care services. The results of this study carried out using the data from the Survey on Health, Ageing and Retirement in Europe (SHARE) suggest that Poland, Italy, and Greece should pay attention to the possible problems associated with the refusal of medical care, which occurred during the first months of the pandemic. A delay in making diagnosis and treatment may ultimately be translated into adverse health effects, deteriorated quality of life, or even enhancement of social and economic inequalities in health which, especially among the elderly, in the coming decades will affect an increasing number of the European population. As indicated, health policy should continue to guarantee an equitable access to healthcare, and also focus on areas outside the health sector (education, employment, social protection, etc.) in order to provide the healthy ageing of the population [36].

Within the study carried out in Poland in 2020, the degree to which the elderly used the Internet was also investigated. According to the data, $71.2 \%$ of persons aged over 60 did not use the Internet, and only every fifth person used the Internet systematically. Those who used the computer regularly described their psychological condition in more positive terms than those who did not use modern technologies. Despite this, the respondents mentioned that the Internet is an ideal way to solve the problem of loneliness, or developing own competences.

The pandemic affected seniors from many different aspects: in a direct way, due to the risk of infection and death, and also indirectly - considering the barrier which increased the feeling of loneliness and isolation caused by impossibility to use public spaces $[35,37]$. While analyzing the results of studies carried out during the pandemic, it should be considered how to modify the parameters of ageing policy in order to adjust them to unpredictable situations. The population in Poland by biological age groups (65 and over), as of 30 June 2021, was 7,175,237. It should be considered that in 2050 the number of seniors in Poland will increase from the present $25 \%$ up to nearly $40 \%$, which will make Polish society one of the oldest in Europe [38, 39].

An important challenge for social and ageing policy is the provision of proper standards of care and health protection, especially during an increased sanitary regime. Recommendations under the auspices of the Polish Psychiatric Association provide very helpful guidelines in the area of adjustment of ageing policy to the current epidemiological challenges. The presented recommendations refer to seniors with dementia, and indicate that social health is the key to the provision of the needs of seniors during pandemic. These recommendations indicate that maintenance of an efficient 
network of contacts, participation in meeting and group activities, may be the source of higher cognitive performance of seniors. In addition, in persons with dementia, social relations are an important factor exerting an effect on slowing progression of the disease. This is also associated with the tendency towards intensive activation of this group by the organization of interventions and psychosocial programmes aimed at the reduction of phenomena perceived as negative, such as social isolation and stigmatization [40]. In addition to the above recommendations, it was indicated that a psychoeducational management plan adjusted to the group of seniors is also indispensable [41].

\section{SUMMARY}

The COVID-19 pandemic allowed a critical evaluation of ageing policy. Analysis of eight available studies conducted during the pandemic showed a decline in the perceived quality of life of seniors, and a deepening social isolation, which are important factors determining the state of psychological, social, spiritual, and somatic state of health of seniors [42]. The review of six governmental and three nongovernmental social activation programmes emphasized the need for the continuation of already existing programmes, as well as implementation of new programmes activating seniors who, from year-to-year, constitute an increasingly larger population. In carrying out the strategy of ageing policy it is important to use the approach of Evidence Based Medicine, Evidence Based Public Health and Evidence Based Health Promotion (EBPH, EBHP) [43, 44]. Limited financial resources require consideration of the catalogue of best practices, which will contribute to the reduction of programmes with low efficiency and unreasonable costs. Therefore, it will be possible to provide adequacy of the actions associated with the social activation of seniors undertaken. In the implementation of the ageing policy it is worth noting and considering the actual needs of seniors determining their quality of life, which will enable delineation of the direction of an effective intervention adjusted to the current sociodemographic situation.

\section{REFERENCES}

1. European Commission. The 2015 Ageing Report: Economic and budgetary projections for the 28 EU Member States (2013-2060). Eur Econ. 2015; 3. doi: 10.2765/877631

2. European Commission. The 2012 Ageing Report.' Economic and budgetary projections for the 27 EU Member States (2010-2060). Eur Econ. 2012; 2 .

3. Mastalski J. Współczesne problemy gerontologiczne w kontekście cywilizacyjnych przemian. In: Pedagogiczne Konteksty Społecznego Wsparcia Rodziny. Uniwersytet Papieski Jana Pawła II. Wydawnictwo Naukowe; 2015 p. 111-178. doi: 10.15633/9788374384247.05

4. World Health Organization. Active ageing: a policy framework. 2002. https://apps.who.int/iris/handle/10665/67215 (access: 2021.10.14).

5. World Health Organization. WHO global report on falls prevention in older age. 2007. https:/www.who.int/publications/i/ item/9789241563536 (access: 2021.10.14).

6. Lee C-J, Hsu Y. Promoting the Quality of Life of Elderly during the COVID-19 Pandemic. Int J Environ Res Public Health. 2021; 18(13): 6813. doi: 10.3390/ijerph18136813

7. Czapiński J, Błędowski P. Aktywność społeczna osób starszych w kontekście percepcji Polaków: diagnoza społeczna 2013: raport tematyczny. Ministerstwo Pracy i Polityki Społecznej: Centrum Rozwoju Zasobów Ludzkich.
8. Garbaccio JL, Tonaco LAB, Estêvão WG, Barcelos BJ. Aging and quality of life of elderly people in rural areas. Rev Bras Enferm. 2018; 71(2): 724-732. doi: 10.1590/0034-7167-2017-0149

9. Filonchyk M, Hurynovich V, Yan H. Impact of Covid-19 lockdown on air quality in the Poland, Eastern Europe. Environ Res. 2021; 198. doi: 10.1016/j.envres.2020.110454

10. Grassi L, Caruso R, Da Ronch C, et al. Quality of life, level of functioning, and its relationship with mental and physical disorders in the elderly: results from the MentDis_ICF65+ study. Health Qual Life Outcomes. 2020; 18(1): 61. doi: 10.1186/s12955-020-01310-6

11. Szukalski P. Dyskryminacja ze względu na wiek jako bariera jakości życia seniorów. Sp - Soc - Econ. 2015; (14): 11-23. doi: 10.18778/17333180.14.01

12. Post M. Definitions of Quality of Life: What Has Happened and How to Move On. Top Spinal Cord Inj Rehabil. 2014; 20(3): 167-180. doi: $10.1310 /$ sci2003-167

13. Theofilou P. Quality of Life: Definition and Measurement. Eur J Psychol. 2013; 9(1): 150-162. doi: 10.5964/ejop.v9i1.337

14. Szatur-Jaworska B. Polityka społeczna wobec starzenia się ludności propozycja konceptualizacji pojęcia. Stud Oeconomica Posnaniensia. 2016; 4(9): 7-27. doi: 10.18559/SOEP.2016.9.1

15. Varlamova M. Active Ageing Index (AAI) in non-EU countries and at subnational level: Guidelines. United Nations Econ Comm Eur Eur Comm Dir Gen Employment, Soc Aff Incl (DG EMPL). 2018.

16. Błędowski P, Szatur-Jaworska B, Szweda-Lewandowska Z, Kubicki P. Raport na temat sytuacji osób starszych w Polsce. Instytut Pracy i Spraw Socjalnych. Warszawa; 2012.

17. Ustawa z Dnia 11 Września 2015 r. o Osobach Starszych. DzU 2015 poz. 1705.

18. Rada Ministrów. Uchwała nr 161 Rady Ministrów z dnia 26 października 2018 r. w sprawie przyjęcia dokumentu Polityka społeczna wobec osób starszych 2030. Bezpieczeństwo-Uczestnictwo-Solidarność.

19. Ministerstwo Rodziny i Polityki Społecznej. Wyniki otwartego konkursu ofert w ramach Programu Wieloletniego na rzecz Osób Starszych „Aktywni+” na lata 2021-2025 - edycja 2021. http://senior. gov.pl/program_asos (access: 2021.10.14).

20. Rada Ministrów. Uchwała Nr 237 Rady Ministrów z dnia 24 grudnia 2013 r. w sprawie ustanowienia Rządowego Programu na rzecz Aktywności Społecznej Osób Starszych na lata 2014-2020. MP201452.

21. Michalewska-Pawlak M, Klimowicz M. The impact of the Government Program for Social Participation of Senior Citizens (ASOS) on social activation of the elderly in Poland: Findings from a qualitative study. Stud z Polityki Publicznej. 2021; 8(1(29)): 9-25. doi: 10.33119/ KSzPP/2021.1.1

22. Sejm RP. Posiedzenie Sejmu nr 27 w dniu 17-03-2021 (2. dzień obrad). https://www.sejm.gov.pl/Sejm9.nsf/wypowiedz.xsp?posiedzenie=27\& dzien=2\&wyp=19\&symbol=RWYSTAPIENIA_WYP\&id=379 (access: 2021.10.14).

23. Ministerstwo Rodziny i Polityki Społecznej. Program „Opieka 75+” na rok 2021

24. Kancelaria Sejmu. Biuro Komisji Sejmowych. Pełny zapis przebiegu posiedzenia Komisji Polityki Senioralnej (nr 15) z dnia 13 kwietnia $2021 \mathrm{r}$.

25. Ministerstwo Rodziny i Polityki Społecznej. Program „Wspieraj Seniora” na rok 2021. https://wspierajseniora.pl/ (access: 2021.10.14).

26. Ministerstwo Zdrowia, Krajowa Izba Fizjoterapeutów. Aktywny senior w domu. Program profilaktyczny Krajowej Izby Fizjoterapeutów i Ministerstwa Zdrowia. https://fizjoterapiaporusza.pl/aktywny-senior (access: 2021.10.14).

27. SzukalskiP. Jakłączyćpokolenia? O roliprojektówmiędzypokoleniowych. Biul Rady do Spraw Polityki Senioralnej. 2021; 1.

28. Leszczyńska-Rejcher A. Edukacja międzypokoleniowa oraz integracja międzypokoleniowa jako wyzwania współczesnej gerontologii. Gerontol Pol. 2014; 2: 76-83.

29. Woźniak Z. Solidarność międzypokoleniowa w starzejącym się świecie - perspektywy i zagrożenia. Ruch Prawniczy Ekon Socjol. 2012; 74(3): 21-63.

30. Caritas Polska. Program Senior Caritas. https://caritas.pl/projekty/ program-senior-caritas/ (access: 2021.10.14).

31. Młodziejewska N. Bezpłatne konsultacje lekarskie dla seniorów w Poznaniu. Studenci Uniwersytetu Medycznego udzielają porad przez telefon i internet. Głos Wielkop. https://gloswielkopolski.pl/ bezplatne-konsultacje-lekarskie-dla-seniorow-w-poznaniu-studenciuniwersytetu-medycznego-udzielaja-porad-przez-telefon-i/ar/c1414918304 (access: 2021.10.14).

32. Caritas Archidiecezji Łódzkiej. Polski konsument w czasach koronawirusa - nowe badanie syndykatowe. IPSOS 2020. Na codzienne 
zakupy 2021/2022. http://www.caritas.lodz.pl/?art=e77d8256ec456e8 10a4dbc30050192e7 (access: 2021.10.14).

33. Gambin M, Sękowski M, Woźniak-Prus M, et al. Generalized anxiety and depressive symptoms in various age groups during the COVID-19 lockdown in Poland. Specific predictors and differences in symptoms severity. Compr Psychiatry. 2021; 105: 152222. doi: 10.1016/j. comppsych.2020.152222

34. Bidzan-Bluma I, Bidzan M, Jurek P, et al. A Polish and German Population Study of Quality of Life, Well-Being, and Life Satisfaction in Older Adults During the COVID-19 Pandemic. Front Psychiatry. 2020; 11. doi: 10.3389/fpsyt.2020.585813

35. Fabisiak B, Jankowska A, Kłos R. Attitudes of Polish Seniors toward the Use of Public Space during the First Wave of the COVID-19 Pandemic. Int J Environ Res Public Health. 2020; 17(23): 8885. doi: 10.3390/ ijerph 17238885

36. González-Touya M, Stoyanova A, Urbanos-Garrido RM. COVID-19 and Unmet Healthcare Needs of Older People: Did Inequity Arise in Europe? Int J Environ Res Public Health. 2021; 18(17): 9177. doi: 10.3390/ ijerph18179177

37. Newman MG, Zainal NH. The value of maintaining social connections for mental health in older people. Lancet Public Health. 2020; 5(1): e12-e13. doi: 10.1016/S2468-2667(19)30253-1
38. Kancelaria Senatu. Starzenie się ludności w Unii Europejskiej - stan obecny i prognoza. Biuro Analiz, Dokumentacji i Korespondencji, 2018.

39. GUS. Ludność. Stan i struktura ludności oraz ruch naturalny w przekroju terytorialnym (stan w dniu 30.06.2021), 2021. https://stat. gov.pl/obszary-tematyczne/ludnosc/ludnosc/ludnosc-stan-i-strukturaludnosci-oraz-ruch-naturalny-w-przekroju-terytorialnym-stan-wdniu-30-06-2021,6,30.html (access: 2021.10.27).

40. Łuc M, Szcześniak D, Trypka E, Mazurek J, Rymaszewska J. Recommendations of the Polish Psychiatric Association: SARS-CoV-2 pandemic and the population with dementia. Psychiatr Pol. 2020; 54(3): 421-436. doi: 10.12740/PP/122780

41. Armitage R, Nellums LB. COVID-19 and the consequences of isolating the elderly. Lancet Public Health. 2020; 5(5): e256. doi: 10.1016/S24682667(20)30061-X

42. Santini ZI, Jose PE, York Cornwell E, et al. Social disconnectedness, perceived isolation, and symptoms of depression and anxiety among older Americans (NSHAP): a longitudinal mediation analysis. Lancet Public Health. 2020; 5(1): e62-e70. doi: 10.1016/S2468-2667(19)30230-0 43. Gotlib J,Belowska J, Panczyk M, Dykowska G, Wójcik G. EBM i EBNP w polskim piśmiennictwie naukowym. Probl Pielęgniarstwa. 2014; (22). 44. Stephen T, Polgar S. Introduction to Research in the Health Sciences. Oxford: Churchill Livingstone, 2013. 